(Hunter tristimulus and transmittance), and subjective evaluation of pork quality $24 \mathrm{~h}$ after slaughter indicated pale soft exudative defects (pale colour, high exudation, loose texture, high transmittance of extracts) in the samples kept at higher temperatures $\left(42.5\right.$ and $\left.40^{\circ} \mathrm{C}\right)$. Drip losses $72 \mathrm{~h}$ after slaughter supported these findings.

Higher temperatures soon after slaughter thus stimulate denaturation of sarcoplasmic proteins, so increasing drip losses and pale soft exudative deterioration of pork.

\title{
References
}

Hart. P.C.. 1962. Fysisch-chemische kenmerken van gedegenereerd vlees bij varkens. 2. Tijdschrift Diergeneeskunde 87: 156-167.

Sybesma, W., 1963. Enterse ziekte onder de huidige omstandigheden: praktische mogelijkheden ter beperking van de schade. Tijdschrift Diergeneeskunde 88: 1043-1049.

Sybesma, W. \& G. Eikelenboom, 1978. Methods of predicting pale, soft, exudative pork and their application in breeding programmes - a review. Meat Science 2: 79-90.

Wal. P. G. van der. G. Eikelenboom \& E. Lambooy, 1983. The effect of electrical stunning on pork quality. In: G. Eikelenboom (Ed.), Stunning of animals for slaughter. Martinus Nijhoff, The Hague, p. $82-89$.

This synopsis is based on a report entitled 'Een modelstudie naar de invloed van de vroeg post mortale spiertemperatuur op de vleeskwaliteit van de m. longissimus dorsi van varkens', Report B-239, Research Institute for Animal Husbandry 'Schoonoord', Zeist, Netherlands, 1984.30 pp., 8 tables, 15 refs. Dutch, English summary and table captions.

Available as paper copy (order R019P, free available) or microfiche (order R019M, f 12.50 including postage) at: NARD, clo Pudoc, P.O. Box 4, 6700 AA Wageningen, Netherlands (telex 45015 blhwg $\mathrm{nl}$ ).

\section{Simulation of the production pattern of rape-seed on the basis of a field experiment}

M. Backx, J. van Duivenvoorden and J. Goudriaan (Department of Theoretical Production Ecology, Agricultural University, P.O. Box 430, 6700 AK Wageningen, Netherlands)

Accepted: 20 August 1984

Abstract. A simulation model for growth and development of rape-seed on the ba- 
sis of laboratory and field measurements gave a final seed yield of $2900 \mathrm{~kg} \mathrm{ha}^{-1}$. Light interception by the florescence caused a seed yield reduction of $5 \%$.

Key-words: rape-seed, simulation, crop growth and development, light interception, SUCROS.

Introduction. A simulation study was done to answer the question whether light interception by the florescence of rape seed causes a considerable reduction of yield.

Material and methods. In 1982 an extensive field experiment with rape-seed Brassica napus L., was carried out in the new land of the Flevopolder by the 'IJsselmeerpolders Development Authority' (RIJP). Two cultivars were used (Jet Neuf and R332), 2 sowing dates (25 August and 6 September) and 2 plant densities ( 80 plants $\mathrm{m}^{-2}$ (normal) and 12 plants $\mathrm{m}^{-2}$ (thinned)). In five periodic harvests several components of the crop were determined, such as dry weight of the leaves, stems, roots, pods and seeds, as well the leaf area index (LAI), the 1000-grain weight and number of seeds and pods. Also oil content, hectolitre weight, the total number of flowers in the entire florescence were determined. The development stage of the crop was followed according to the scale of Habekotte (1978).

Photosynthesis-light response measurements were carried out by using the equipment of the CABO described by Louwerse \& van Oorschot (1969).

The simulation model was an extension of the model SUCROS (Penning de Vries \& van Laar, 1982).

Results. For the simulation study only one subject was used: cv. Jet Neuf, density 80 plants $\mathrm{m}^{-2}$ and sowing date 25 August. In the model the time course of the crop properties was not related to date but to stage of development. For the time being it was assumed that the temperature sum is the only factor that determines the development stage. According to the scale of Habekotte the crop goes through a total of 15 stages covering ca. 1700 degree-days with a threshold temperature of $4{ }^{\circ} \mathrm{C}$. On its turn the development stage determines the partition of the assimilates over the different organs, and also the death rate of the leaves.

These relationships were collected in the field experiment itself so this is not an independent simulation. The stability of these relations has to be tested in other years.

Photosynthesis-light response measurements showed that young leaves and pods had the same maximum rate of $40 \mathrm{~kg} \mathrm{CO}_{2} \mathrm{ha}^{-1} \mathrm{~h}^{-1}$ and a light use efficiency of $0.5 \mathrm{~kg}$ $\mathrm{CO}_{2} \mathrm{ha}^{-1} \mathrm{~h}^{-1} \mathrm{~m}^{2} \mathrm{~s} \mathrm{~J}^{-1}$. These values are rather high for a healthy $\mathrm{C}_{3}$ crop. Even green stems showed $1 / 5$ of this photosynthetic capacity.

To estimate the light interception by the flowers the absorption, reflection and transmission spectrum of light was measured. In the blue region (wavelength $<490$ $\mathrm{nm}) 95 \%$ of the light is absorbed by the flowers, whereas at a wavelength $>540 \mathrm{~nm}$ (yellow, red and near infrared) only $5 \%$ is absorbed, with an almost linear transition in between (wavelength between 490 and $540 \mathrm{~nm}$ ). Like in leaves, reflection and transmission hardly differ.

At full flowering there are 5000 flowers per $\mathrm{m}^{2}$, each flower with an area of 2.8 


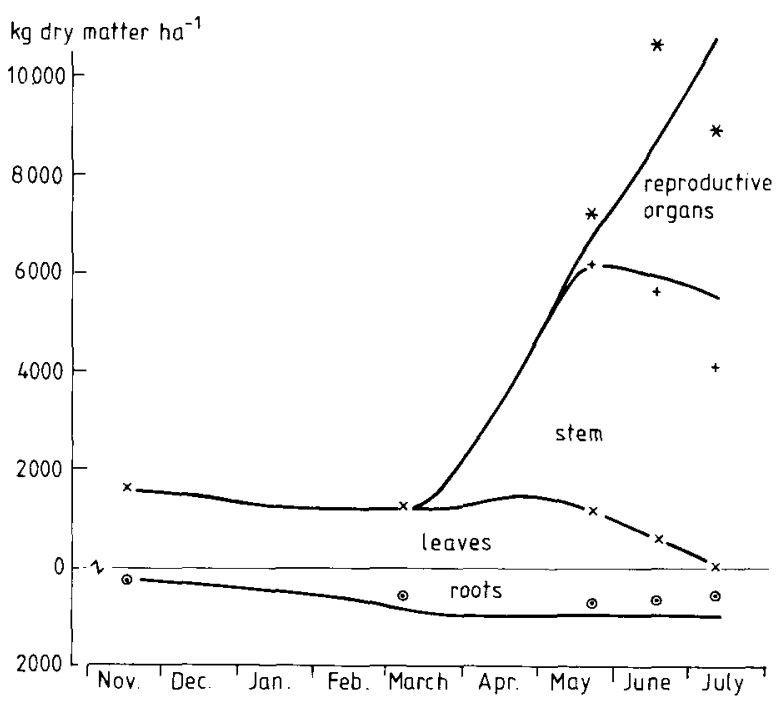

Fig. 1. Time course of measured $(*,+, \times, 0)$ and simulated (solid lines) dry matter of the major organs of rape-seed (Brassica napus L.).

$\mathrm{cm}^{2}$. The measured transmission of $55 \%$ in the field is in agreement with these numbers. During a period of 4 weeks (end April to end May) a total of 14000 flowers per $\mathrm{m}^{2}$ are produced. The light reduction during this period is entered into the photosynthesis section of the model. The assimilates, as calculated in the photosynthesis section, were used for respiration and growth. Respiration is strongly influenced by temperature and also depends on the fat- and protein content of the plant. From $1 \mathrm{~g}$ glucose, ca. $0.7 \mathrm{~g}$ vegetative material can be produced, but only $0.3 \mathrm{~g}$ oil or fat. At an oil content of $23 \%$ in the entire pod this leads to an average production of $0.53 \mathrm{~g}$ pod dry matter from $1 \mathrm{~g}$ glucose.

The simulated final yield was $2900 \mathrm{~kg} \mathrm{ha}^{-1}$. The results of the simulation are in good agreement with the field experiment except for the decline of total dry matter at the end of the growing period (Fig. 1). Probably translocation and conversion of assimilates and nitrogenous compounds cause high respiration losses. Although the input data about partitioning were derived from the field experiment itself, the agreement of the total dry matter yield is not obvious because photosynthesis and respiration are calculated independently.

From the results of the model the reduction due to light interception by the florescence is estimated as $4 \%$ in total dry matter yield, $8 \%$ in stem weight and $5 \%$ in seed weight. This reduction is rather small, partly because light is intercepted above the saturation level for photosynthesis and partly because the time span for flowering is short in relation to the total growth period.

Recommendations for further research on rape-seed concern:

- first development after sowing in autumn 
- the death rate of the leaves during the whole growing season

- translocation and conversion of constituents at the end of grain filling

- crop photosynthesis measurements

- more detailed simulation of the development stage

- testing and improvement of the model with experiments under different conditions.

Acknowledgements. Thanks are due to the RIJP, Prof. G. J. Vervelde and Mrs H. H. van Laar.

\section{References}

Habekotte, A., 1978. Schaal voor de morfologische ontwikkeling (groeistadia) van winterkoolzaad. Lelystad, RIJP-rapport, $15 \mathrm{pp}$.

Louwerse, W. \& J. L. P. van Oorschot, 1969. An assembly for routine measurements of photosynthesis, respiration and transpiration of intact plants under controlled conditions. Photosynthetica 3: 305-315.

Penning de Vries, F. W. T. \& H. H. van Laar, 1982. Simulation of plant growth and crop production. Simulation Monographs. Pudoc, Wageningen, $308 \mathrm{pp}$.

This synopsis is based on an $M$. Sc. thesis entitled 'Simulatie van het produktiepatroon van koolzaad aan de hand van een veldproef bij de Rijksdienst IJsselmeerpolders te Lelystad', Department of Theoretical Production Ecology, Agricultural University, Wageningen, 1984.116 pp., 42 figs., 7 refs., 4 appendices. Dutch.

Available as paper copy (order R020P, $f 30$ including postage) or microfiches (order R020M, f 17.50 including postage) at: NARD, clo Pudoc, P.O. Box 4, 6700 AA Wageningen, Netherlands (telex 45015 blhwg $n l$ ).

\section{The influence of the phosphorus concentration in the diet on the performance of fast-growing pigs}

A. W. Jongbloed (Institute of Livestock Feeding and Nutrition Research, P.O. Box 160, 8200 AD Lelystad, Netherlands)

Accepted: 22 August 1984

Abstract. The effect of different $\mathrm{P}$ concentrations in cereal- and byproduct-based diets on performance was studied in growing pigs from 30 to $110 \mathrm{~kg}$ live weight. An 